\title{
The Timely Traditions of Albert Herring
}

\begin{abstract}
Every summer, for seven summers now, Is a had heard the same words; about the hammer and the nails; the pageant and the weather. Every year they said, would it be wet or fine; and every year it was-one or the other. The same chime followed the same chime, only this year beneath the chime she heard: "The girl screamed and hit him about the face with a hammer." - VIRGINIA WOOLF, BETWEEN THE ACTS $(1941)^{1}$
\end{abstract}

Set in the idyllic grounds of an English country house, Virginia Woolf's Between the Acts tells of the preparation and performance of a village pageant on the eve of war. As the spectacle journeys through literary history, the villagers respond with mixed reactions that turn to frustration as they search in vain for a useful "message." By setting the novel in the shadow of war, Woolf stages a collision between the pageant and apocalyptic events. Yet it is not simply the play but also the manners and habits associated with it that come to appear unacceptably trivial. While Lucy Swithin frets about posters, rain, and the interval spread, Isa Oliver reads in the newspaper of soldiers raping young girls. No longer capable of speaking to modern experiences, cultural tradition becomes a mode of escape. It allows people to imagine community and continuity where there is division and destruction, to block their eyes and ears to more pressing concerns. But far from simply dismissing the pageantry of the past, Woolf's novel revels in it; its sporadic allusions to contemporary events are overshadowed by an emphasis on historical continuity, its satirical send-ups are suffused with affection, and the pageant's pastiche spills over into the novel proper. For all the self-consciousness about nostalgia's pitfalls, in other words, Between the Acts offered traditional images at a time when tradition was under threat. In doing so, it implicates itself and its readers in the very myopia it diagnoses.

Premiered six years after the publication of Between the Acts, Albert Herring (1947) presents many of the same critical problems. Set in the turn-of-the-century Suffolk countryside, the opera tells the tale of a group of village busybodies who revive the tradition of crowning a virtuous "May Queen." When no young lady is deemed suitably virtuous, they crown Albert-a naïve greengrocer-as "May 
King” instead. Spurred on by some rum-laced lemonade, Albert takes off for a night of drunken debauchery, rebelling against the social strictures for which he has become a mascot. When he returns home, he asserts his independence, teaching the village worthies a valuable lesson. ${ }^{2}$ Much like Woolf's novel, Herring plays with themes of obsolescence, nostalgia, and irrelevance, sketching traditions that were bound to appear precious in the shadow of war.

It is perhaps unsurprising, then, that Britten's opera has provoked many of the same critical misgivings. As Michael Kennedy pointed out in his biography published in 1981, Albert Herring appears to represent a regrettable retreat from the cosmopolitanism and contemporaneity of Britten's previous forays into the operatic genre. ${ }^{3}$ Like most other critics, however, Kennedy advanced this perspective as a pretext to deny it, defending the opera from the charges of conservatism that it would otherwise seem to invite. As recently as 2008, Paul Kildea drew on an identical strategy, insisting that "more contemporary concerns" were buried beneath the ostensibly nostalgic surface. ${ }^{4}$ Although such defenses have often been couched as revelations, they depend on strategies that date back to the opera's premiere in 1947. By tracing these fraught responses back to their roots, I want to reframe Albert Herring's apparently paradoxical position-at once serious and trivial, timely and traditional, original and obsolete-as another window into the mid-century mediation of the great divide.

\section{STAGING TRADITION}

In staging the tension between timeless traditions and mid-century concerns, Woolf's novelistic swansong grappled with a subject close to the heart of her generation. Since the early decades of the century, her contemporaries had characterized theirs as a period qualitatively different from those before, one that required radically new forms of art as a result. While Wyndham Lewis announced the end of history, Ezra Pound's injunction to "make it new" appeared to capture the general mood, with the effect that scholars have often nominated the desire to break radically with tradition as modernism's raison d'etre. ${ }^{5}$ In recent years, scholars have worked to nuance modernist "myths of originality," yet-as we have seen-they nevertheless were important in shaping the way critics and artists understood their cultural battle lines. ${ }^{6}$ In a series of essays from around 1920 , Woolf herself dismissed late Victorian and Edwardian literature as irrelevant to her generation. ${ }^{7}$ On the one hand, her frustration was the customary aesthetic one: that their idiosyncrasies had hardened into styles and conventions, working against the creativity and originality of younger writers. On the other hand, the obsolescence of past literature was said to reflect fundamental changes: "In or about December, 1910," Woolf famously wrote, "human character changed." Edwardian materialism, she explained, with its obsession with buildings, possessions, and manners, could only appear unacceptably trivial in the perilous modern world. 
Such consensus only grew louder as the century continued, and war and devastation once again loomed. By 1938, Woolf's accusations had widened to encompass not just Victorian and Edwardian fiction but all past literature: "We are not here to sing old songs or to fill in missing rhymes. We are here to consider facts. . . So let us shut the New Testament; Shakespeare, Shelley, Tolstoy and the rest, and face the fact that stares us in the face at this moment of transition." 9 According to Jane de Gay, Woolf's writing from the late 1930 s and early 1940 s testifies to "an almost physical discomfort in trying to read literature at a time when more urgent issues command[ed] attention," a discomfort that spilled over into Between the Acts in the figure of Isa Oliver. ${ }^{10}$ As one of the younger generation, Isa carries the weight of the modern world on her shoulders, plagued as she is by the violent stories she reads in the newspaper. Most others, by contrast, are so immersed in the past that they are oblivious to the present. When the village elders sporadically turn their attention to contemporary politics, for instance, they explain it away as part of the routine upheavals to which people have always been subject, as if to embody the myopia born of cultural tradition. ${ }^{11}$

For writers, one of the most obvious solutions was to eschew traditional plots and subjects in favor of themes that engaged the present. "The historian today," Woolf opined in 1936, "is writing not about Greece and Rome in the past, but about Germany and Spain in the present; the biographer is writing lives of Hitler and Mussolini, not of Henry the Eighth and Charles Lamb; the poet introduces communism and fascism into his lyrics; the novelist turns from the private lives of his characters to their social surroundings and their political opinions." ${ }^{12}$ In the year Woolf worried about literature's irrelevance, Britten's friends and collaborators, W. H. Auden and Christopher Isherwood, were being championed for their "outspoken topicality," dealing "not only with dictators and war, but boldly and sincerely with the problems which dictatorship and war have set for every member of the audience." ${ }^{13}$ By the early 1940s, it was not just the usual left-wing subjects that flew topicality's flag. While few would be surprised by George Orwell's assertion that "a novelist who simply disregards the major public events of the moment is generally either a footler or a plain idiot," even T. S. Eliot began to defend artistic timeliness. ${ }^{14}$ In an essay from 1940, Woolf herself explained:

To-day we hear the gunfire in the Channel. We turn on the wireless; we hear an airman telling us how this afternoon he shot down a raider; his machine caught fire; he plunged into the sea ... Scott never saw the sailors drowning at Trafalgar; Jane Austen never heard the cannon roar at Waterloo. Neither of them heard Napoleon's voice as we hear Hitler's voice as we sit at home of an evening. ${ }^{15}$

Although Woolf was all too aware of the pitfalls of a culture that looked to the past instead of the present, she was willing neither to turn her back on literary tradition nor to embrace a narrow topicality. Even as she derided convention as "ruin" for the modern writer, she warned of going too far in severing links with the past. ${ }^{16}$ 
On the one hand, she defended conventions as the building blocks of communication, comparable to the common greetings exchanged "as a prelude to the more exciting intercourse of friendship." ${ }^{17}$ On the other, she admitted deriving pleasure from familiar conventions in and of themselves: "I confess I cry out for the old decorums, and envy the indolence of my ancestors who, instead of spinning madly through mid-air, dreamt quietly in the shade with a book." ${ }^{18}$ This desire for a lost innocence by no means subsided in her later writings as the urge to break with tradition took on new political imperatives. Even after diagnosing the complicity of English cultural tradition in Fascism, Woolf still found herself tempted "to listen not to the bark of the guns and the bray of the gramophones but to the voices of the poets, answering each other, assuring us of a unity that rubs out divisions as if they were chalk marks only." ${ }^{19}$ Much like the village elders that she satirizes, she drew comfort and perspective from past literature, along with the sense of continuity offered by literary tradition.

Whether in the early reception of Britten's works or the most recent scholarship, commentators have shown themselves similarly preoccupied with matters of timeliness. Throughout the 1930s, Britten's collaborations with the likes of Auden and Isherwood yielded the kind of "topical" films and plays that Woolf lamented. ${ }^{20}$ For those eager to uncover such a preoccupation with war, violence, and oppression in Britten's operas, his first two essays in the genre were veritable gifts. Peter Grimes appeared to wear its timely concerns on its sleeve with the persecution of its misunderstood protagonist symbolizing the modern "loss of innocence." First performed while Europe was clearing its rubble, it was partly this that endeared it to postwar audiences. As we saw in the previous chapter, Edmund Wilson praised the work's topicality, as much a matter of style as of subject matter. ${ }^{21}$ With the exception of the Christian epilogue-to which critics, tellingly, objected-The Rape of Lucretia (1946) staged a similarly bleak trajectory, representing lost innocence graphically through the onstage rape of its chaste heroine.

After these two tragic operas, the composer advised readers of Life magazine that his third would "depart from somber themes and be a 'comedy of manners." ${ }^{22} \mathrm{He}$ told $\mathrm{BBC}$ listeners that the work's very raison dêtre was to provide light relief from its "serious" and "gloomy" operatic siblings. At least one critical preview offered a similar warning, insisting that Herring "promises a lot of surprises . . . to any who may not imagine the composer of 'Peter Grimes' and 'Rape of Lucretia' as a humorist." ${ }^{23}$ Although advocates have stressed affinities between Albert Herring and Peter Grimes, the former could just as easily be described as an inversion of the latter: while Grimes stages the undoing of its outsider protagonist, Herring depicted a much more positive rite of passage. ${ }^{24}$ As the climax to the original synopsis made clear, Britten's comic opera is ostensibly a tale of triumph over adversity: "[Albert] has plunged into unforgivable excesses-but at least he has learnt the value of his own independence and can stand up for himself in the future."25 
As Laura Mooneyham has pointed out, this kind of comic optimism was at odds with modernism's ascetic ideals and-at least in highbrow circles-came to seem virtually obsolete by the Second World War. ${ }^{26}$ In a context in which art was supposed to have lost its innocence, critics were put off by comedy's triviality and naïveté. According to Jonathan Greenberg, satire-with its "double movement" between affirmation and destruction - fared much better than straightforward comedy, but some still declared its critical edge too subtle to survive. ${ }^{27}$ "Satire," Auden explained in 1952, flourishes "in times of relative stability and contentment, for it cannot deal with serious evil and suffering." ${ }^{8}$ "In an age like our own," he continued, "it cannot flourish except in private circles as an expression of private feuds; in public life, the serious evils are so serious that satire seems trivial and the only possible kind of attack is prophetic denunciation." No matter how pointed the satire, then, there was always the risk of getting caught up in the play with obsolete conventions and styles. Indeed, according to P. G. Wodehouse, it was not just the pessimism of the age but also the cult of originality that had rendered comedy-with its reliance on traditional plots, characters, and turns of phrase - an anachronism. ${ }^{29}$ This conventionality is even more pronounced in the "comedy of manners," the subgenre to which Albert Herring belongs, which flaunts convention as both style and subject matter.

Britten's opera, no exception, is "about" tradition and suffused with it. It was based on Guy de Maupassant's "Le Rosier de Madame Husson" (1887), a short story about the endurance of customs in the rural French village of Gisors. In transplanting Maupassant's tale to the fictional Suffolk village of Loxford, Britten and Crozier retained this emphasis on tradition even as they introduced implications of lateness and obsolescence into their tale. Much as in Between the Acts, the characters divide sharply between the village elders, blindingly faithful to past traditions, and the younger generation, for whom these traditions are irrelevant and restrictive. From the moment the curtain rises, Lady Billows, the self-appointed guardian of custom, can be heard lamenting changes in village life: the new custom of putting poppies in the altar vases, the laxity of the choirboys' responses, and the immorality of the young make her blood boil. Soon after, she delivers an ode to tradition- "There's a lot of wisdom in these old / traditions"-before embarking on a nostalgic trip down memory lane:

Competition to be May Queen

When I was a girl was amazingly keen!

Among the village girls, I mean.

All dressed in white -

Met on the Green

At noon on May the First to parade

Before the Squire.

Squire picked the winner

And sat beside her during dinner. 
Oh! You're too young to remember

How these things were done! $!^{30}$

For Lady Billows, traditional values are bound up with the pomp and ceremony of English cultural tradition. She is, of course, right to speculate that the younger generation neither knows nor cares "how these things were done"; Albert and his peers regard the May Day tradition as a nuisance, if not a downright embarrassment. Indeed, this indifference propels the plot, as the Loxford establishment struggles to "make virtue attractive, exciting, desirable for young people." ${ }^{31}$ In this respect, Herring was responding to-even staging-contemporary critiques of tradition in much the same way as Woolf. Yet however much Maupassant's reverential treatment of tradition was tempered by self-conscious implications of obsolescence, the opera's subject matter still afforded a pretext to revel in all kinds of references to the past-from archaic settings and conventional themes to stock characters and stylized dialogue.

Perhaps the most obvious nod to the past was in the opera's "provincial" setting. ${ }^{32}$ The story's rural village setting symbolized "provincial" historicism: a space where time appears to stand still. According to Britten and Crozier, one of the most important tasks in adapting the story was to transport it to a comparable English setting, settling on the fictional town of Loxford (adapted from Yoxford), around Ufford, Orford, Iken, and Snape. Mention of these towns and villages recurs throughout the opera and, even at a distance of fifty years, Nancy Evans recalled the audience's gleeful recognition of the quaint old English place names: "Every time we mentioned Iken and Snape, the Saxmundam Police are out-and that sort of thing-they just all sort of giggled and started stirring every time something local was mentioned ... a terrific response to that." ${ }^{33}$ In reveling in the details of its local setting, Albert Herring appears to have skated close to the edge of what Orwell called "the nostalgia of place names," a late Victorian and Edwardian tradition of using archaic-sounding places to evoke sentimental images of "buried villages, thatched roofs, and the jingle of smithies." 34

The provincialism of the opera's subject matter was mirrored in the setting of its first production at Glyndebourne-a private estate deep in the East Sussex countryside. In staging the opening scene in a country house, its producers sharpened these reflections and offered a nod to English literary tradition. The country house was, after all, a bedrock of the national literary heritage: from Northanger Abbey to Brideshead Revisited, authors had drawn on it as a symbol of timeless historical continuity and a metaphor for cultural patrimony with all its privileges and problems. Although the composer and the librettist had supposedly pushed forward the date of Maupassant's tale by just over a decade-from 1887 to the turn of the twentieth century_critics speculated that John Piper's country house setting (Fig. 3) belonged firmly to the nineteenth century. One apparently even felt the need to apologize: "If the room belongs rather to 1880 than to 1900 (the date of 


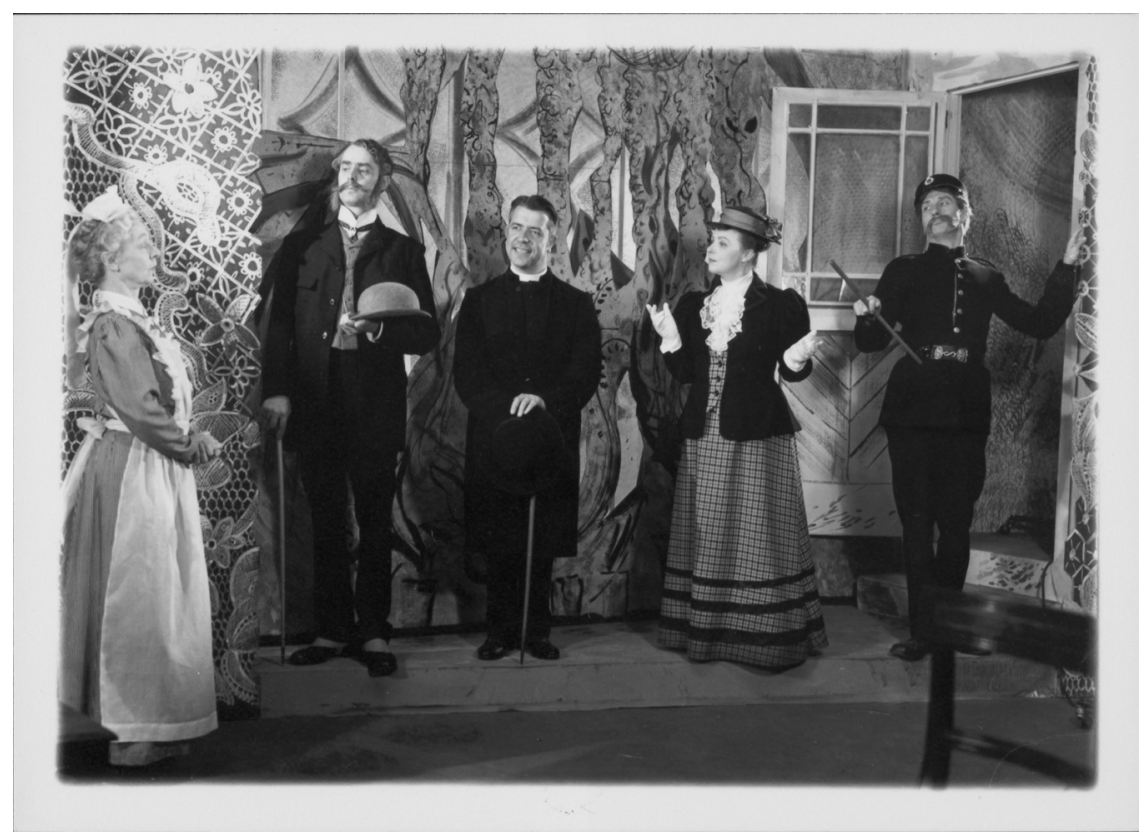

FIG. 3. Production Photograph of Albert Herring, Act I Scene 1, Lady Billows's Breakfast Room, June 1947. Photographer: Angus McBean. ( ) Harvard Theatre Collection (MS Thr 581), Houghton Library, Harvard University.

'Albert Herring'), well, Mr. Britten's Lady Billows was old-fashioned in 1900."35 While this commentator was reminded of Henry James's The Spoils of Poynton (1896) - a novel about a houseful of dusty antiques - others were content simply to bask in the old-fashioned details of Piper's handiwork: "If I cavil a little at the too farcical appearance of the police constable and the too fussy acting of Lady Billows's housekeeper, I have otherwise nothing but praise for the stylized late Victorian profusion of John Piper's designs (above all, those clothes!)." ${ }^{36}$ Whether Piper's set designs were from the 188 os or the 190os, he tapped into the long-standing symbolism of the setting, much as Woolf's description of Pointz Hall had done in Between the Acts. One of the few details that he included in his sketches was a series of ancestral portraits (see Fig. 4), hardly a subtle symbol of cultural heritage.

If the country-house setting was the most obvious bow to tradition, the stock characters drew the most criticism. In a radio interview and Listener article from 1937, Lord Elton pared "highbrow" antipathy to conventional characterization down to its quintessence: "We smile ... at what appear to us to be the stilted and unnatural conventions in the Victorian novels our grandparents read." ${ }^{37}$ Citing characters from Gilbert and Sullivan's Trial by Jury (1875), he elaborated: "The 


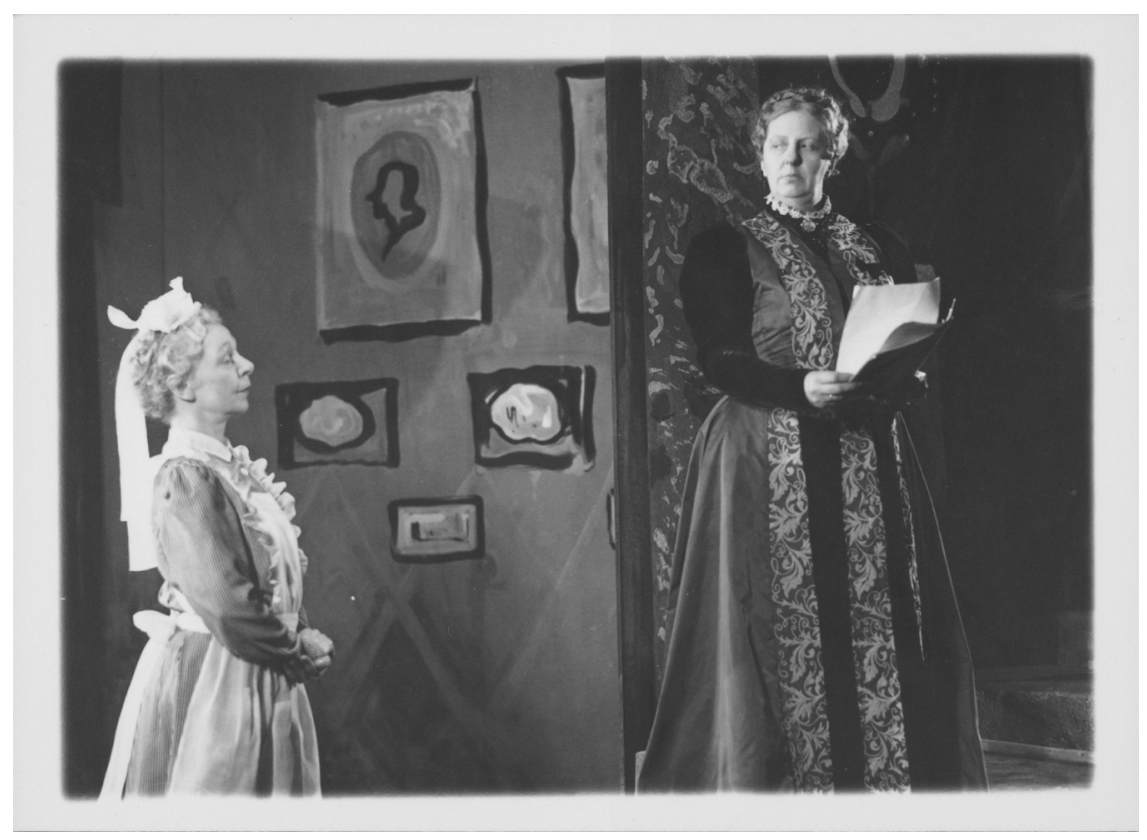

FIG. 4. Production Photograph of Albert Herring, Act I Scene 1, Portraits on the Wall, June 1947. Photographer: Angus McBean. @ Harvard Theatre Collection (MS Thr 581), Houghton Library, Harvard University.

blushing Angelina, the whiskered Edwin seem to us mere figures of pasteboard." For actual critics, the problem was naturally a little more complicated. Q. D. Leavis complained that novelists had traditionally substituted boldness and familiarity for the subtleties of reality, while Woolf lamented Edwardian neglect of the "inner" mind in favor of the "outer" signs-the stylized possessions, clothes, and interactions-of conventional characterization. ${ }^{38}$

In good modernist fashion, Crozier initially sought to inject the stock personages of Maupassant's story with "hints of an individual way of life." ${ }^{39}$ By the time it came to penning the actual dialogue, however, complexity and originality had taken a back seat to theatrical economy: "I wanted to introduce Lady Billows straightaway as a beneficent local tyrant, actively concerned with good works, narrow in her views, and meddling in all the affairs of the town." ${ }^{40}$ After revising early drafts and erasing inessential detail, he was left with a more "conventional" cast than in Maupassant's original. Although Crozier intended to represent Lady Billows as a "beneficent ... tyrant," her "benevolence" is-unlike her French counterpart-quickly replaced with a more familiar moral conservatism. For one critic, this "Victorian matron" archetype was representative of the wider cast, who "with one exception are not human beings [but] well known comic types," drawn 
from the national literary heritage..$^{41}$ One commentator complained that the work "is not a comic opera, but a rendering in opera of the English comedy," while another listed the familiar characters:

Lady Billows, an elderly autocrat, ... her house-keeper, more rigid than her mistress, whose list also recorded the behavior of the village girls; Miss Wordsworth, prim head-teacher at the school; the dear Vicar; the pompous Mayor; the rustic Superintendent of Police; the local greengrocer and her son, Albert Herring; Sid from the butcher's; Nancy from the bakery, and three tiresome village children. Nothing could be more English. ${ }^{42}$

If Lady Billows was the most obvious relic of literary history-amalgamating the moral evangelism of Middlemarch's Nicholas Bulstrode with the dogmatic conservatism of Galsworthy's Soames Forsyte-Superintendent Budd came a close second. In transforming Maupassant's proud Commandant Desbarres into a bumbling police superintendent, "heavy, slow-thinking and a good sort," Crozier was doffing his cap to the simple but warmhearted police officers of literary tradition. It was to such a character that Woolf had turned in Between the Acts, when she represented "The Nineteenth Century" with the "husky and rusty" police constable known as Budge..$^{43}$ In his devotion to Empire and lament for a policeman's lot, Superintendent Budd exhibited striking affinities with Budge, not to mention the Sergeant of Police from The Pirates of Penzance (1880).

Along with conventional characterization went stylized dialogue. For despite the creators' aspirations to drag opera's "creaky" texts into the modern age, Herring often sounds every bit as dated as the examples Britten and Crozier denigrated. ${ }^{44}$ One reason for this was the "controlled verse" in which the libretto was cast, fitting oddly with pretensions to everyday, realistic dialogue. Perhaps even more significant was the verse's clichéd content, such as the "Good Morning" (Act I, Scene 1) ensemble's extended paean to the timeless English tradition of discussing the weather:

MAYOR

Wonderful weather for April, Mr Gedge!

SUPER

Wants oiling, I expect. Dust in the works ...

MISS WORDSWORTH

Look! that hedge of rosemary is humming with bumblebees!

VICAR

Quite perfect, Mr Mayor. Promises a splendid May and June.

MAYOR

That it does- 


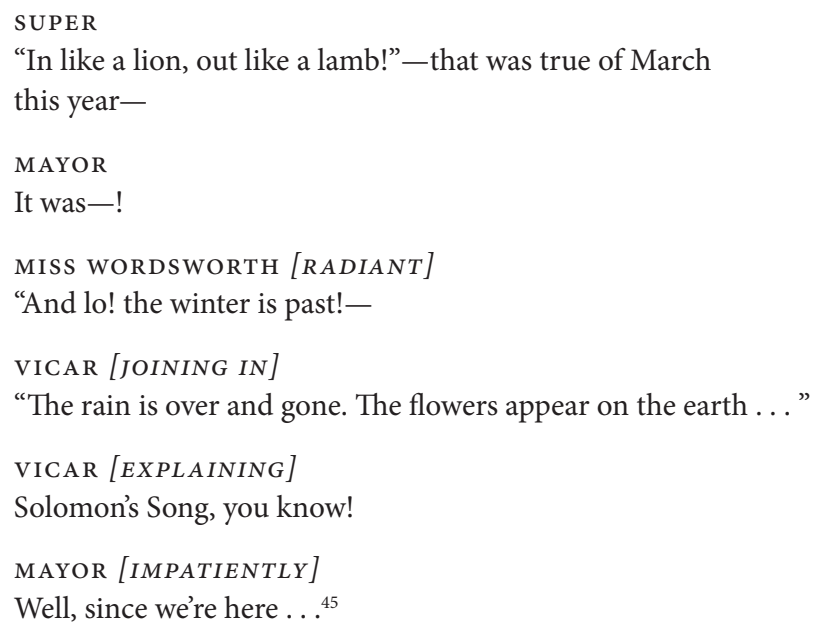

Stylized communication is imagined here as closer to ritual than to genuine interaction, with verbal and literary commonplaces affording a mode of conversing without actually making contact. As Miss Wordsworth and the Vicar carry on about the weather, Superintendent Budd remains stuck in the previous conversation, pondering-appropriately - the cause of his watch's tardiness.

Ultimately, however, it is an actual literary allusion-a half-baked memory of the Song of Solomon-that pushes the Vicar and Miss Wordsworth over the edge, so far into a different world that the Mayor is forced to pull them back with an impatient quip, "Well, since we're here." As he directs attention away from these "old songs" and "missing rhymes" - to borrow Woolf's words-toward the immediate item on their agenda, poetry becomes marked as an emblem of nostalgia, drowning out the concerns of the day. Nor is this the only-or even the most extreme-example of a shift from cliché to quotation, as Lady Billows's Act II speech makes clear:

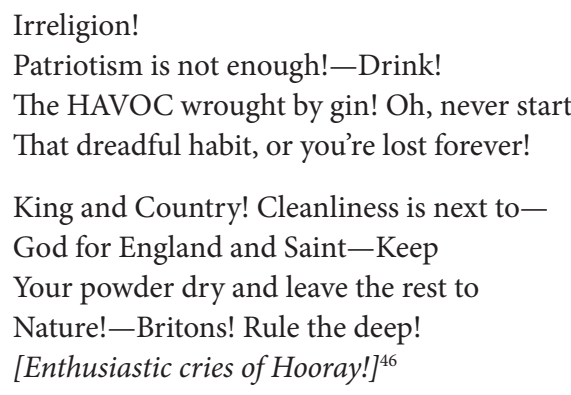

Such an outburst demonstrates how Crozier marks convention as a relic of the past that impedes engagement with the present. This pile-up of literary non-sequiturs epitomizes the extent to which old sentiments, sayings, and 
quotations abound, heightening the opera's cartoonish conventionality of style and subject matter.

\section{SEARCHING FOR TIMELINESS}

Where timeliness and tradition were widely supposed to be mutually exclusive, one might have expected Albert Herring to draw criticism for nostalgia and myopia. Sure enough, after observing that the "characters are largely conventional skits on figures of village life," Martin Cooper insisted that "it is not enough to create flat, cardboard figures of fun and proceed to laugh at them." ${ }^{47}$ Complaints were also raised in connection with the provincial setting: one critic lamented that "a salacious French story of Maupassant [had been] translated by Eric Crozier into a rustic English comedy of the way a bumpkin kicks over the traces," while another criticized the turning of "one of Maupassant's most cuttingly ironic stories ... into a comedy of Suffolk village life that leaves nothing but its indestructibly funny situations." ${ }^{48}$ Other commentators noted the lack of a meaningful story line: "Albert's binge is expected. Nothing comes of it: and it has, of course, to be watered down, for polite English ears," Anderson complained. ${ }^{49}$ Richard Capell, by contrast, dealt with this ambivalence by appealing to wishful thinking and imagining a more "modern" interpretation:

Was not a really modern Cocteauesque version possible? Cocteau would have looked for something more interesting for the centre-piece of a libretto than the sight of a young greengrocer being drunk for the first time. He would have known that neurasthenia is not cured by rum. One pictures a Cocteauesque scene with the greengrocer undergoing some drastic sort of electric therapy (“E. C. T.") to rid him of his feeling of deference for his mother. Albert Drunk! One felt quite embarrassed by the naïveté of the young authors. ${ }^{50}$

Yet despite the many features seemingly calculated to make mid-century critics anxious, Herring was not widely written off. If, as Michael Seidel has argued, the satirical impulse always involved subverting the very conventions upon which it relied, it is easy to see how even seemingly affectionate examples of satire could be recuperated as a form of modernism. ${ }^{51}$ Many reviewers did so, casting the opera as more serious and timely than it appeared. "I venture a prediction," Hans Keller wrote even before the premiere: "The serious musical aspect of this lyrical comedy will tend to be underestimated, or even neglected." ${ }_{52}$ Keller was one of many who redirected charges of superficiality from Britten's opera to those who called it that..$^{53}$ After positing that "real humor is obvious . . . but cannot exist without an underlying seriousness," he identified deeper levels of meaning that inexperienced critics were apparently guaranteed to miss:

There seem to be one or two parallels between Albert Herring and Britten's two previous operas, quite apart from formal principles, scoring (Lucretia), and setting (Suf- 
folk: Peter Grimes). I am thinking of a number of psychological and sociological correspondences, e.g. the motif of sullied chastity (treated from the tragical point of view in Lucretia), or the theme- "opposition to (society's) tyranny," which plays such an important part in both Grimes and Lucretia. I thought this might be worth mentioning as there is bound to be much ado about "how different" Albert Herring is from anything previous. ${ }^{54}$

As Keller's exegesis makes clear, it was not just modernist rhetoric of surface and depth but also the comparison with Grimes and Lucretia that was wrested from would-be detractors. Although Herring's broader trajectory appears a world away from its operatic siblings, Keller initiated a defensive trope that came to dominate the work's reception. Given the forcefulness of his rhetoric, it is not difficult to understand why: by denigrating the imaginary philistine who opts for the "obvious" interpretation, Keller virtually assured that commentators would pay lip service to such "psychological and sociological correspondences." 55 One critic focused on affinities between Albert and the eponymous hero of Britten's first opera: "In short, A. Herring (brilliantly created by Peter Pears) is a social misfit like Grimes." ${ }^{6}$ After asking, "Why, then, did Britten choose such a subject?" another responded similarly: "because of the 'hero'-an odd character like Grimes, not an ordinary accepted member of society. Mr. Britten obviously sympathizes with such characters." 57 More emphatically, Lockspeiser argued that "some element of uncontrollable frustration appears in the heroes of each of Britten's operas-even more so in 'Albert Herring', perhaps, than in either 'Peter Grimes' or 'The Rape of Lucretia." ${ }_{58}$

The episode on which a large part of the defense's case rested comes in Act II, Scene 2, when Albert returns home from his coronation banquet. As the inebriated protagonist reflects on his humiliating day, he sets off on an extended monologue, perhaps more at home in Mrs. Dalloway than Carry On, Jeeves Crozier temporarily gives the conventional village idiot a more sensitive soul. After overhearing Sid's condescending cliché- "heaven helps those who help themselves"-Albert lays his feelings bare, making it clear that his problems are not born of simple ignorance:

\footnotetext{
ALBERT

"Heaven helps those who help themselves."

"Help myself!" Oh go, go away

And leave me here alone

With doubts and terrors

You have never known ... !

Enjoy your evening as you will!

Kiss and hug your fill! Embrace until

The stars spin round like Catherine-wheels

Against the rainbow-covered hills.
} 


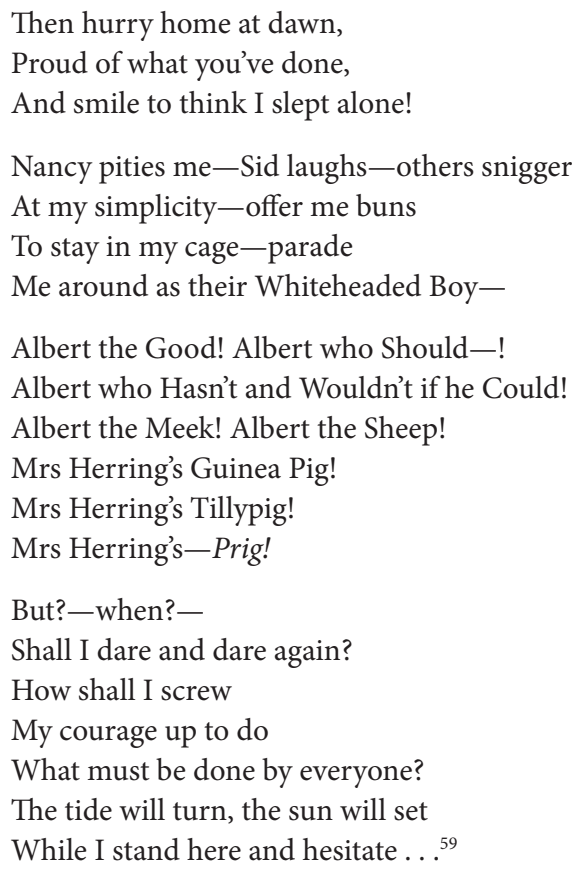

Unlike the moralistic proclamations of Lady Billows or Sid's fun-loving ditties, Albert's monologue moves rapidly between conflicting themes and sentiments. To the frustration, isolation, and oppression that critics touted in connection with Grimes, one may add self-pity, anxiety, fear, and impatience-all tempered by determination and even resolve. Such an outpouring would have surely reminded critics of the "mad scene" from Britten's first opera, which-as we have seen-was also associated with post-Freudian characterization. Like Septimus Smith, Leopold Bloom, and Peter Grimes, Albert is haunted by the voices of his mind. In drawing on modernist stream-of-consciousness, the librettist invited deep-rooted psychological speculation from audiences and critics who were only too happy to oblige. While Charles Stuart predicted that "opera-goers of a certain sort are sure to start grubbing frantically for bits of Freud between the lines," Capell confirmed: "in the interval at Glyndebourne, the word went round that Albert represented a psychological problem, and, that his revolt against a strong-willed mother ... contained a meaning and a moral."60 Much as with Keller, the underlying meaning of the rebellion was less important than its existence per se. For, with just a little squinting, they could frame it in modernist terms. Even commentators who did not directly invoke Freud could sense that Albert was cast from an entirely different mold than the other characters: "Albert Herring is after all no mere laughing stock, like the half-wit in Smetana's 'The Bartered Bride, but a gentle and essentially sensitive being with a secret longing for love (witness his delicious song about Nancy in the second act)." ${ }^{\text {61 }}$ 
Apart from injecting the opera with a frisson of literary modernism, this gesture to isolation and conflict encouraged critics to hear the serious concerns of the modern world after all. An even more common means of staking a claim for timeliness was by touting the opera's "tragic" elements over its comic ones. As Christopher Herbert has pointed out, even the most casual use of adjectives such as "serious," "tragic," and "realistic" as terms of praise stemmed from modernist aesthetics of timeliness and existentialism. ${ }^{62}$ In the account of one critic, the impression that "'Herring' casts longing glances at the somber drama of 'Grimes"” served as a prelude to a sustained attempt to rescue the composer and his work: "one feels that, like Verdi, with whom he [Britten] has more in common than one might expect, he is inclined to look for drama and even tragedy in the most inconsequential and frivolous farces . . . and he will surprise you with almost tragic outbursts after scenes of immense gusto." ${ }^{3}$ For another commentator, the opera redeemed itself only through these "moments of intense seriousness," "an expense of spirit in a waste of brittle giggling." ${ }^{4}$ Besides Albert's aforementioned monologue, there was one other place to which these critics looked-the final-act threnody for the "deceased" protagonist. Quite apart from its general morbidity ("death awaits us one and all"), its grief-stricken sentiments struck a familiar postwar chord ("that one so young should die in vain"). While Lockspeiser commended the ensemble as "a very moving dirge with hardly a touch of comedy in it," Neville Cardus heard the "poignant threnody" as redeeming the work "from almost parodistic origin to significant life capable of revealing sore wounds and pitiable humanity." ${ }_{5}$ For Shawe-Taylor, it was moments such as the "solemn threnody" that "make it a superficial judgment to write the work off as a farce or a charade." 66

Commentators were under no illusions about the rarity of these "melancholy echoes." But while the extent to which these tragic moments tipped the interpretive scales in the opera's favor is striking, it is easy to understand why they kept commentators scratching their heads. In offering "tantalising glimpses" of a level of sentiment otherwise unplumbed, they exposed a hermeneutic void that audiences were eager to fill. The threnody, in other words, angles for the cryptographic attention it has received, marking itself as a beacon that illuminates the entire opera. For Clifford Hindley, both the monologue's pathologizing sense of Albert as "different" and the threnody's tragic seriousness spoke to the protagonist's homosexuality. ${ }^{67}$ Still more recently, Paul Kildea has identified pacifist and socialist meanings bubbling up from exactly the same fissures. ${ }^{68}$ But while the specifics of interpretation have changed, the sense of these passages as game changers has remained. ${ }^{69}$ In violating the opera's unity and consistency, these passages arguably functioned as "unconsummated"-even unconsummatable-symbols, inviting interpretation while simultaneously evading definitive readings. In marking timeliness as an absence rather than a direct presence, they encouraged critics to justify their enthusiasm for the opera in terms of hidden depths, even as they heightened the playful superficiality of the rest of the work. By highlighting the 
opera's pressing omissions, it excuses them, allowing audiences simultaneously to revel in and disavow the opera's nostalgic myopia.

\section{ALBERT'S MUSICAL REBELLION}

Much as in the literary sphere, musical modernism was often associated with extreme antipathy to tradition, whether this was true in practice or not. Schoenberg became the poster boy for this radicalism, despite the nuances and complexities of his own position. Over a decade before Adorno's apocalyptic account of Schoenbergian "progress" in The Philosophy of Modern Music (1949), critics were already lamenting the extremism of what Constant Lambert irreverently dubbed the "Official Revolution." ${ }^{\circ}$ If Adorno would declare only a handful of composers sufficiently original to qualify as modernists, Lambert satirized antipathy to tradition as an oppressive bandwagon:

To the seeker after the new, or the sensational, to those who expect a sinister frisson from modern music, it is my melancholy duty to point out that all the bomb throwing and guillotining has already taken place ... there are few composers who are not attached, either officially or unwittingly, to some revolutionary "movement."

While remaining sympathetic to the desire to cast off the "shackles" of conventional musical form, Lambert insisted that "revolutionaries" ended up submitting to an even more debilitating restriction..$^{72}$ Three years later, Cecil Gray complained that "the possession of a wholly individual utterance, or mode of thought, quite unlike that of any one else" had come to be regarded as the artistic "sine qua non" in the wake of musical modernism. ${ }^{73}$

Even a cursory glance at early commentary reveals that the "official revolution" figured as a consistent presence in Britten criticism-an orthodoxy against which the composer was apparently in constant need of defense. In parodying the "cult of contemporaneity," Keller sought to do exactly that. ${ }^{74}$ Elsewhere, recalling Adorno's disparaging remarks about the "new conformism," Keller complained that Schoenbergian standards were being applied with "dramatic lack of success, to the avant-garde and Britten (or Shostakovich or Hans Werne Henze) alike."75 Defending Britten from charges of eclecticism, Charles Stuart offered a similar parody, rejecting extreme radicalism as a modernist cliché:

Against extraneous manners and styles the composer sat on watch and ward year in and year out, with anxious biting of nails. Down went two pages of sonata firstmovement or cantata to text by Walt Whitman at his hairiest. Then you went over what you'd written with a weedfork, uprooting reminiscences: here the ghost of a Pelléas phrase, here a stray bar from Le Coq d'Or, here a fleck of Franck, here, God help us, an echo of the Silver Rose music in Rosenkavalier. A man was mortally afraid to be anybody but himself. He defiantly flashed his identification card long before the thing had been invented. ${ }^{76}$ 
According to Keller and Stuart, Britten's critics fell victim to the "old fallacy of music history's straight line" (a mythical vision of artistic progress that prevented composers ever looking backward) and the "new fallacy that it is important for a work of art to express its own time." 77 Postwar anti-traditionalism was apparently so severe that, by 1953 , critics and scholars were stirred to intervene with a scholarly volume defending Britten from charges of conservatism. ${ }^{78}$

If the composer's defenders were right, one might well have expected such charges to arise in discussions of Albert Herring, surely the record holder for the sheer variety of its borrowed musical voices. While Lady Billows delivers her diatribes in the voice of Handelian ceremony, the Vicar waxes lyrical on the nature of "virtue" in broad Victorian ballads. ${ }^{79}$ Even Sid and Nancy, the opera's least obviously stylized characters, trade in pastiched popular song idioms. Yet, in actuality, the number of writers who described the opera as a patchwork was relatively small. Where one critic worried about the lack of an authorial voice beneath all the stylistic assimilations - "its parody is, indeed, so terribly clever that there are grounds for fears concerning the possible development of a composer to whom so many styles and emotions are fair game"-another limited his concerns to "moments when the music suddenly shifted from authentic Britten to a kind of generalized operatic world of sentiment." ${ }^{\circ \circ}$ But except for such mild and infrequent critiques, charges of conservatism were raised exclusively by those at pains to deny them.

Justification of pastiche was sought in characterization. ${ }^{81}$ "Each character," one critic wrote, "has his own musical accompaniment, from the bassoon obbligato which speaks for the village policeman, the cool Anglican melodies of the Vicar, the vigorous Handelian percussion for the awe-inspiring Lady of the manor, to the lyrical scena of Albert's long self-examination." ${ }^{82}$ Meanwhile, Shawe-Taylor had fun identifying the codes, as if practicing a kind of stylistic listening:

The downright "old English" character of Lady Billows comes out in frequent bursts of Handelian polyphony and an addiction to bluff rhythms and diatonic tunes; the schoolchildren acclaim Albert in a song as square as the toes of their boots; the Vicar's characteristic melodic contours suggest a Shropshire or Devonshire origin; and Albert's "Mum" contemplates a seaside photograph of her son to the strains of a pier-head valse. ${ }^{83}$

Yet even as he reveled in the familiar styles, Shawe-Taylor felt the need to denigrate them, laying the blame for "bluff rhythms and diatonic tunes" at the characters' rather than the composer's feet. By doing so, he could create a layer of narrative distance between Britten and his flagrantly conventional musical material.

Irony could also serve to rationalize pastiche. In commending Britten's "burlesque of grand operatic strokes," for example, Dyneley Hussey appeared to invoke an exclusively musical form of irony, as if the composer were making a point about operatic tradition quite apart from the specifics of the tale. ${ }^{84}$ Some critics even attempted to steer Herring's music away from the affectionate realm of "parody" or "burlesque" toward a more self-consciously modernist form of irony. This meant 

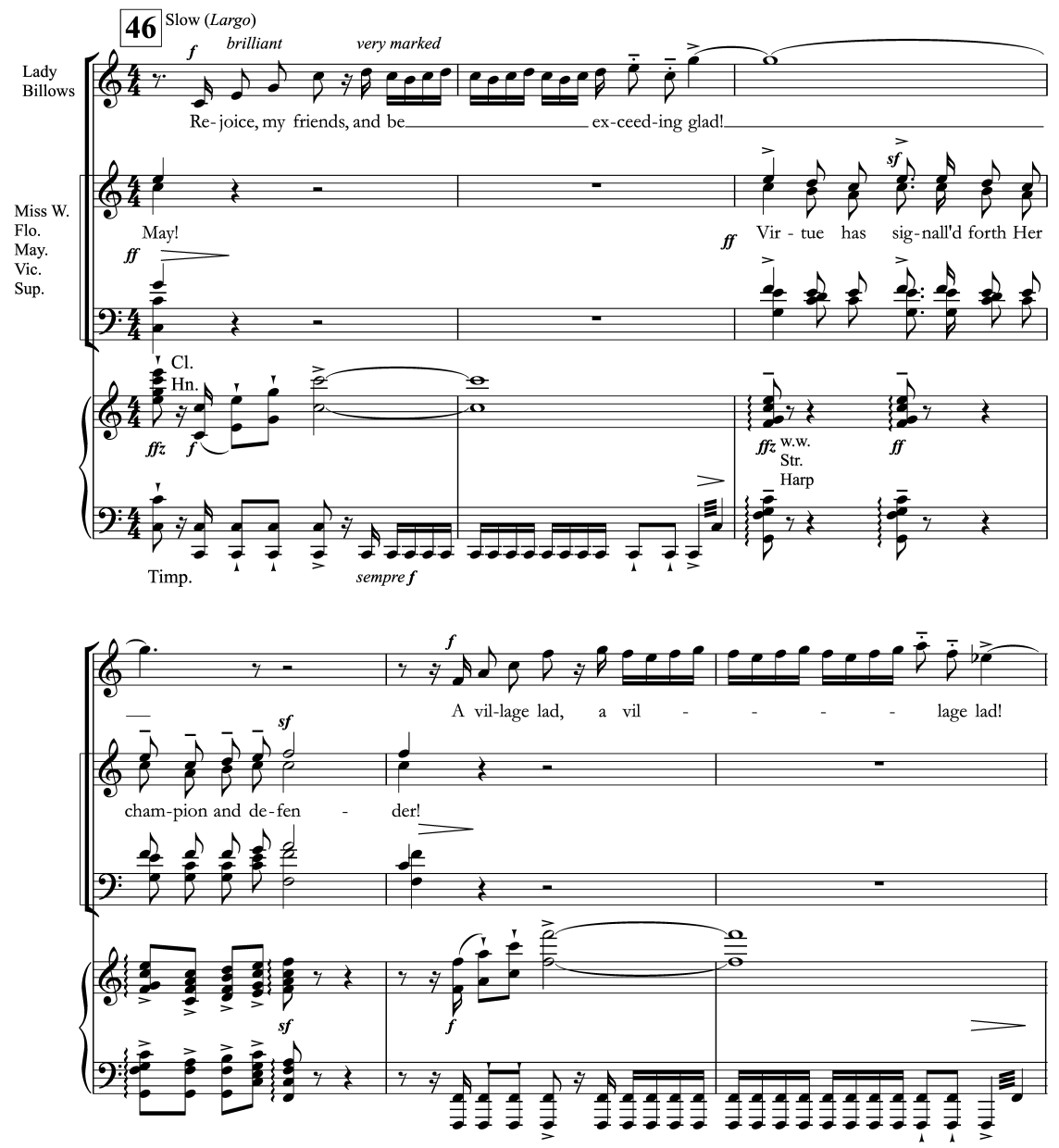

EX. 7. Albert Herring (Act I, Scene 1) — "Rejoice, My Friends".

comparing it with the "rib-nudging" music of Prokofiev and Shostakovich in order to capture "all the leg-pulling and italicizing Britten indulges in." ${ }_{5}$ Such was the pressure to find a guiding authorial voice that many of the composer's staunchest supporters denigrated his music in order to defend it. While Keller described the opening music as "intentionally idiotic," Hussey observed that the score "at one moment lapses ridiculously into the lush manner of Puccini and at another resolves into a four-square Handelian ensemble ... [and] vocal floridities in the old operatic style." 86 To the common vocabulary of "parody," "burlesque," and "satire," some added adjectives like "banal," "pompous," and "absurd" to foreclose the possibility that something as eclectic as "Rejoice, my friends" (Ex. 7) might also be sincere. 
Some commentators, however, found it difficult to reconcile this cynical rhetoric with Britten's charming music. Already by 1949, the Earl of Harewood had grown tired of the tendency to denigrate the music as if parody and pleasure were mutually exclusive: "Parody has its place in Albert Herring, but there is a far a more important side to the score and that is Britten's genuine comic musical invention, which is copious, tuneful, sustained and to the point." 87 "Albert's coronation anthem," Harewood insisted, "is both irresistibly funny and musically enchanting." Others echoed this defense: "In spite of such links [to musical tradition], the whole score remains immensely characteristic of its composer." ${ }^{88}$ Phoebe Douglas engaged in a more extreme form of reverse psychology, hailing the opera as a lesson in musical timeliness and originality:

There are many who dislike modern music, finding it weird and dissonant, and prefer to pacify their hearts and ears with older, smoother melodies. But the certainties of other days are gone; we no longer believe in the Divine Right of Kings, or go to bed happily bolstered by a sense of superiority over those who work for us. Britten's music is of our age; its tapestries depict our search for beauty and integration, and are an artistic contribution toward the resolution of the doubts and confusions that hedge us about. ${ }^{89}$

For Douglas, it was not despite but because of its traditionalism that Herring spoke successfully to the age's uncertainties. Concentrating on the dissonances sporadically added to the pastiche forms, she concluded: "Britten has given the musical threads of tradition a new and more virile twist. His use of melodic line, spurned by many recent musicians as 'old fashioned' and redolent of a supposedly decadent classicism, reaches a new and modern power of interpretation." ${ }^{\circ}$ Cardus likewise pointed to "shadows of harmony" as the sites of the composer's idiosyncratic musical "signature."

If there was a point at which the composer's originality was most palpable, it was in the Act 2 monologue, marked, as everyone agreed, by psychological depth. To evoke the memories and conflict that make up Albert's interior crisis, Britten recapitulated a medley of themes from the previous scene, adding dissonances and exaggerating their characteristic features. The most prominent musical material comes from Albert's coronation anthem ("Albert the Good"), first introduced by the Vicar before being taken up as a choral finale to the banquet scene. In its original form (Ex. 8), the pseudo-baroque melody appears in a largely unsullied $\mathrm{B} b$ major. Already by the beginning of the following interlude (Ex. 9), it is transformed from its ceremonial character into a more playful fugue subject. Although the fugue begins regularly enough, the formality is quickly undermined as the counterpoint veers off into aimless sequences before borrowing a conspicuously "modern" voice. (See Ex. 10.) Together with the attenuated tonality, displacing the theme's intervals over several octaves mimics a Second Viennese Klangfarbenmelodie while maintaining the cadential gestures of the original. Any 
43 broadly (largamente)
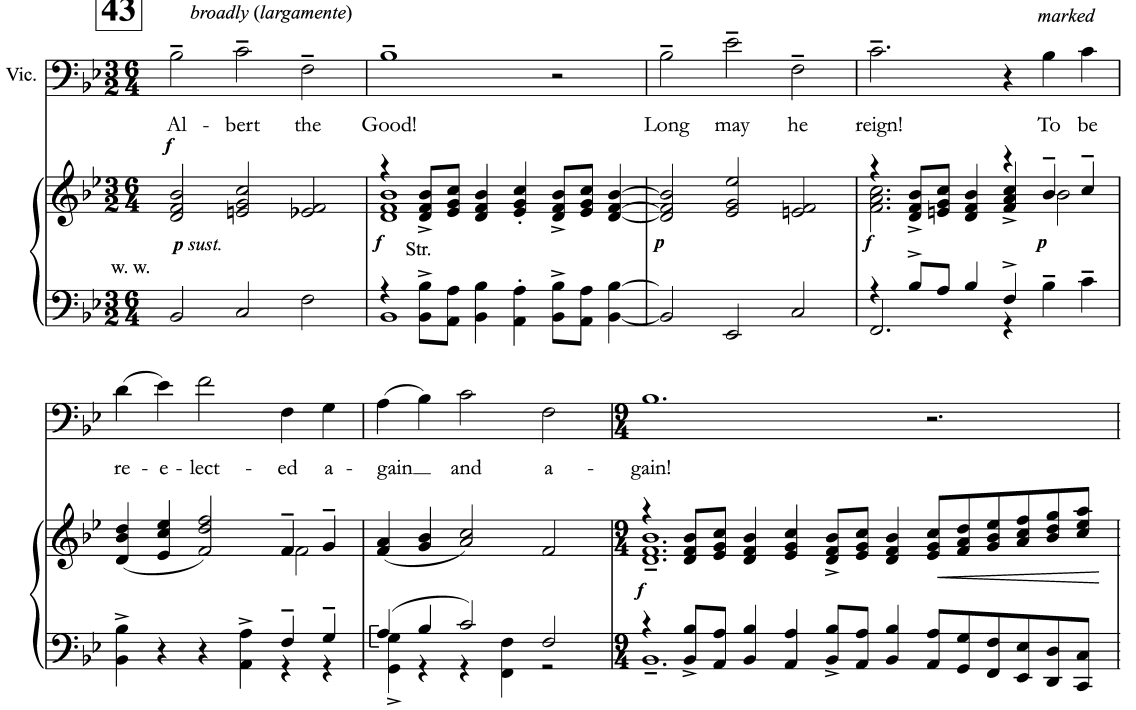

EX. 8. Albert Herring (Act II, Scene 2) - "Albert the Good".

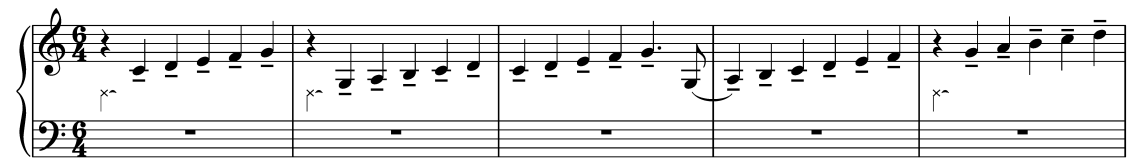
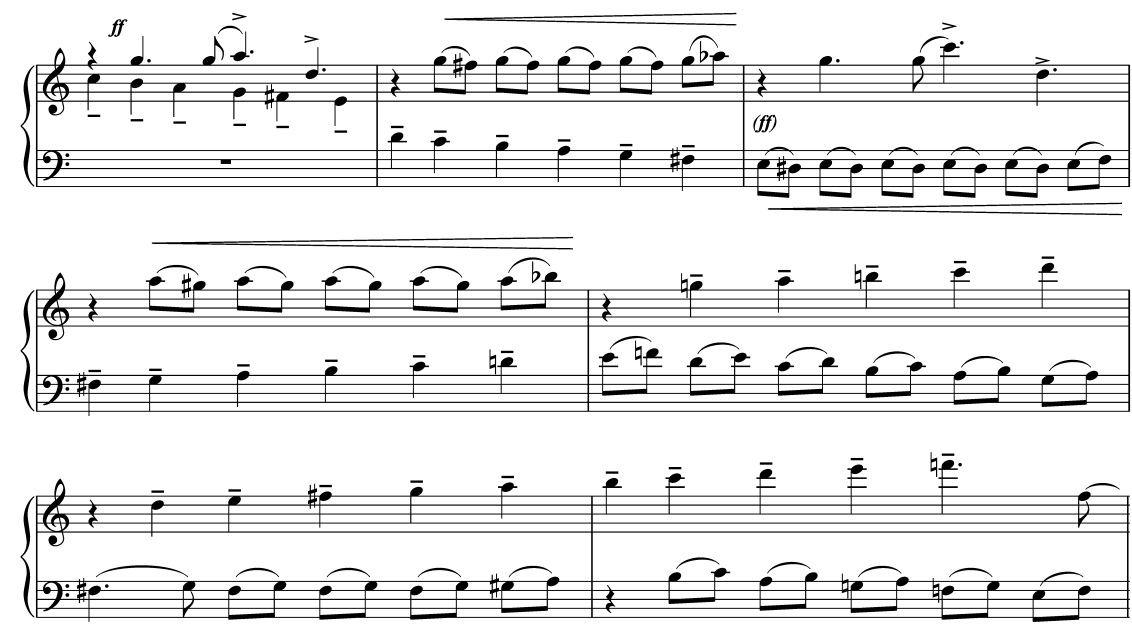

EX. 9. Albert Herring (Act II, Interlude)-Fugue. 
50
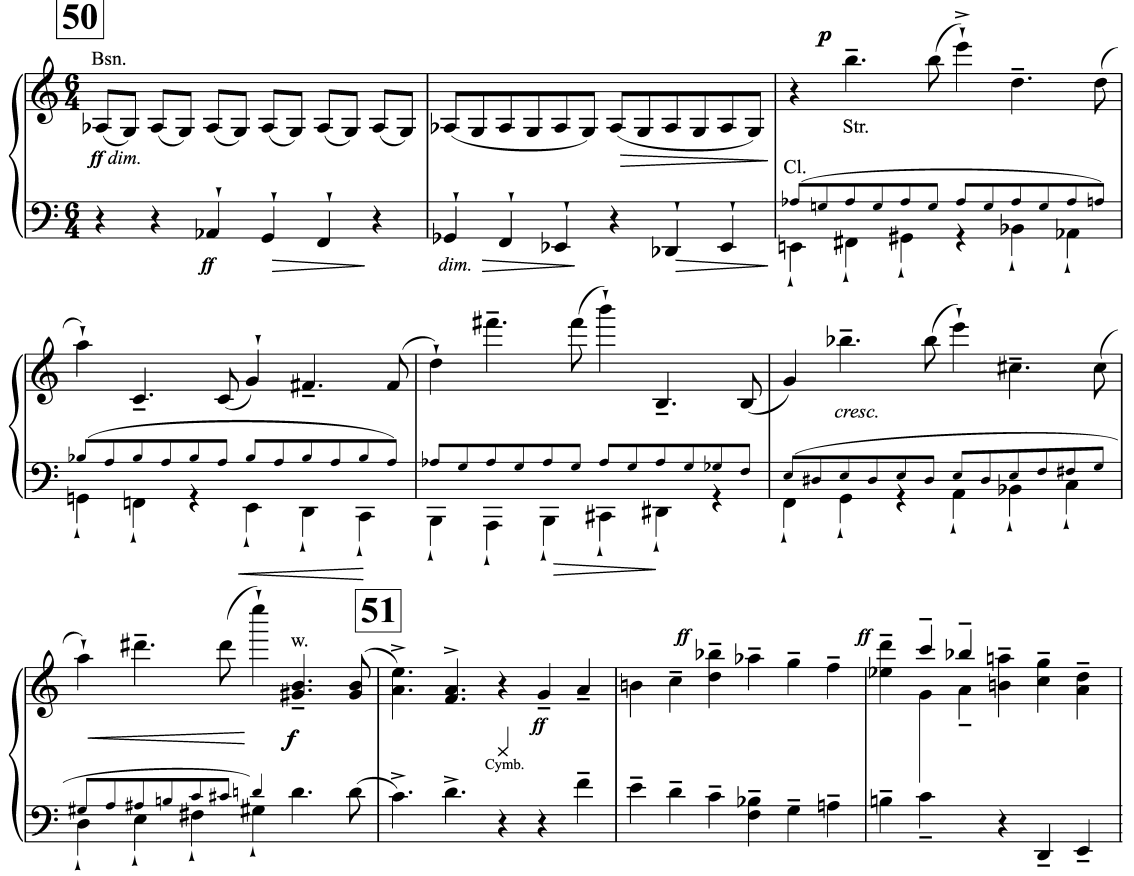

EX. 10. Albert Herring (Act II, Interlude)_ “Klangfarbenmelodie”.

doubts as to whether the interlude is a metaphorical challenge to the coronation music are erased when Albert takes over the theme in the following scene (Ex. 11). As he enters the shop, inebriated from his lunchtime cocktail, he mangles the coronation anthem, repeatedly bashing the door and extending the tail to the fitting words "and again, again, again." The final stage of this literal and musical rebellion comes just before the protagonist skips off for his night of debauchery. As he mocks his own subservience to his elders (Ex. 12), the block chords accompanying the coronation anthem are spiced with dissonant major seconds, standing at a tritone's remove from the tonic key.

For the Times critic, this was the "scene of real dramatic tension in which Albert finds his soul."92 After worrying that it "may seem a trifle out of place in this rollicking farce," another commentator concluded that the music "succeeded in investing Herring's experiences with a certain poignancy," thanks to the "melancholy echoes of Grimes." ${ }^{\prime 3}$ Lockspeiser went even further, suggesting not simply that the monologue was original but-more radically—that it was "about" originality itself, "a lesson ... of artistic independence, which an artist must continually strive to achieve and maintain." ${ }^{94}$ 

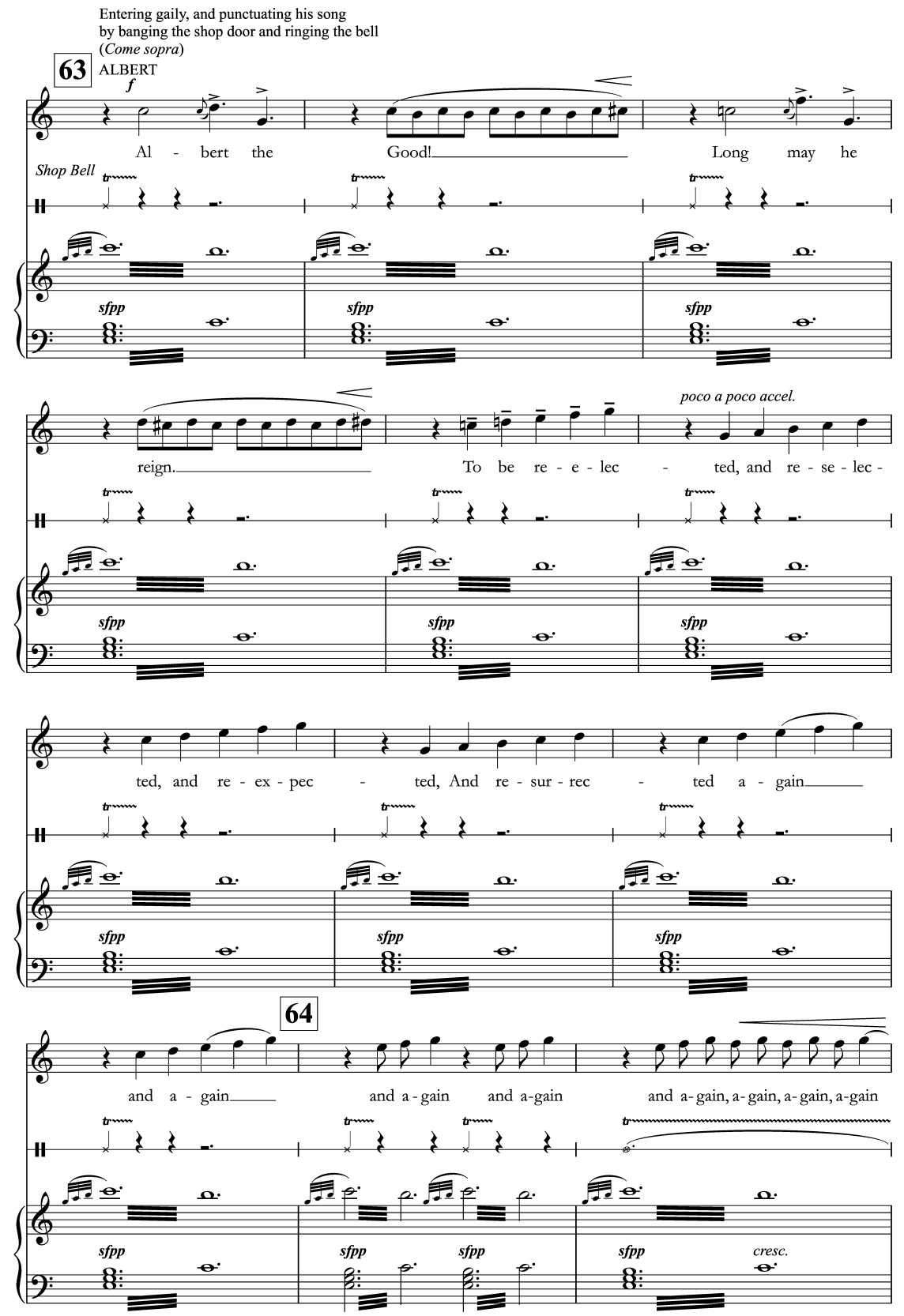

EX. 11. Albert Herring (Act II, Scene 2)-Opening of Monologue. 

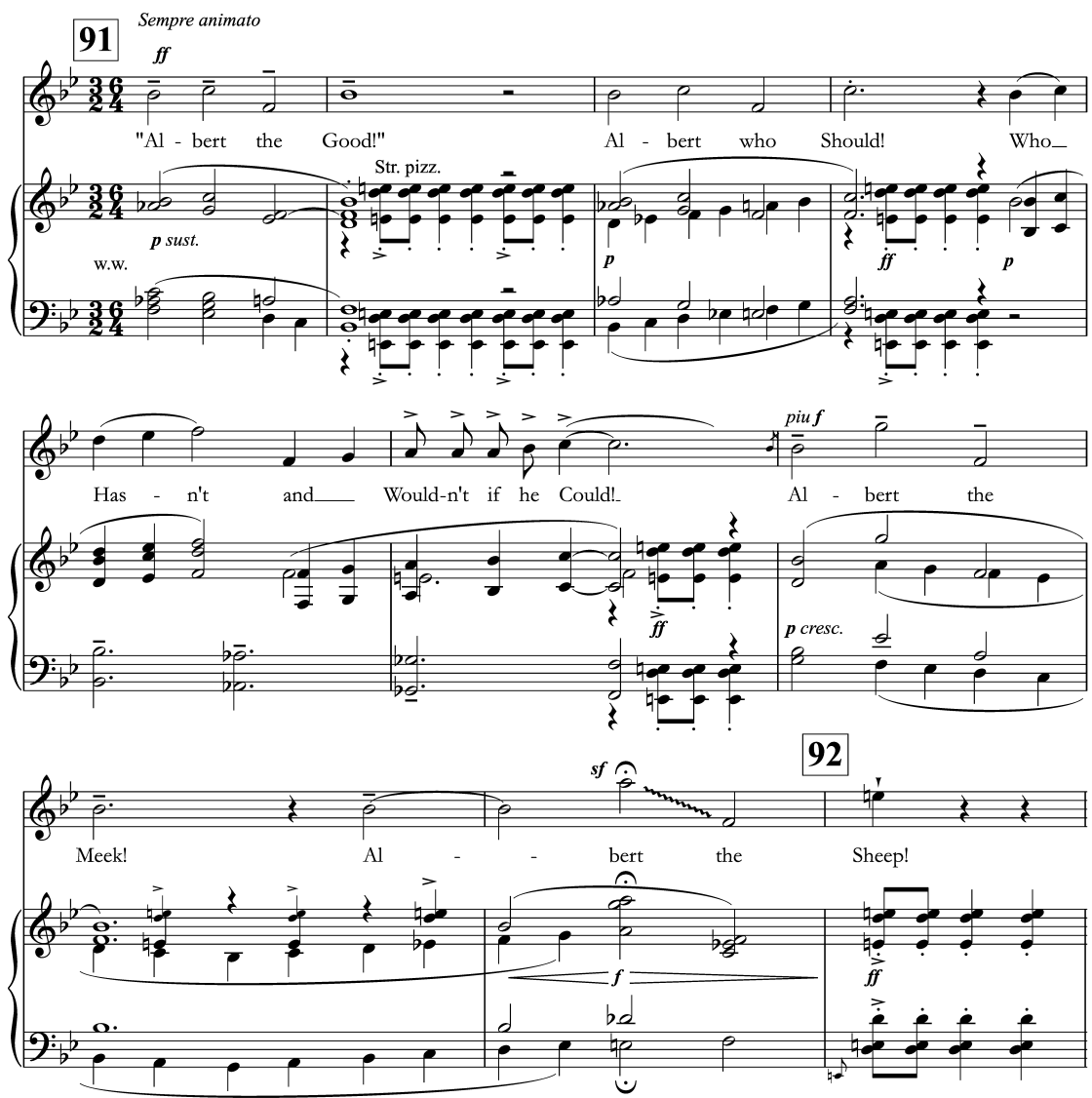

EX. 12. Albert Herring (Act II, Scene 2)-End of Monologue.

In focusing on a single scene as the site of Britten's true voice, commentators exemplified a critical proclivity diagnosed in T. S. Eliot's oft-cited “Tradition and the Individual Talent" (1918): "the tendency to insist . . . upon those aspects of [a poet's work] in which he least resembles anyone else."95 On the contrary, Eliot maintained, "if we approach a poet without this prejudice we shall find that not only the best, but the most individual parts of his work may be those in which the dead poets, his ancestors, assert their immortality most vigorously." ${ }^{96}$ While Eliot's essay has often been seen as a reactionary response to modernism-a nostalgic attempt to rescue the past-a more nuanced reading may help to explain Albert Herring's paradoxical reception. Far from simply valorizing one side of a binarism, Eliot reframed the opposition as a dialectic: it was not simply that the most "traditional" parts of an artwork often turned out to be the most "individual," but that the two concepts depended on each other for their definition. ${ }^{97}$ Already by the 
1930s, this idea was being invoked by mainstream music critics in order to challenge "the official revolution." According to Lambert, for example, the innovation that modernists prized could only be perceived as such if set against tradition: "a background of classicism (like realistic style of surrealist painters) provides the essential norm without which much of the abnormalities would pass unnoticeda discordant harmonization of a familiar tune like 'God Save the King' would be much more of a shock than any given fourteen bars in an atonal work." ${ }^{98}$ Herring's monologue, with its discordant version of his anthem, could have been written to illustrate the point.

In staging the composer's originality less as an authorial presence than as a rhetorical gesture of deformation, the monologue bears out this dialectical reading powerfully. On the one hand, framing tradition as a "mere" pretext for innovation allowed critics to overlook the bulk of the opera's musical language. On the other hand, the "twists," "shadows," and "angles" to which they redirected attention ended up pointing to the conventions they sought to erase. Whenever critics spoke of the composer's "modernisms," it was always in relation to the conventions Britten had apparently transcended. While such a dialectical account may appear simply to reframe an outmoded aesthetic binary that today's sensibilities would sooner have us throw out, it has the potential to clarify and defuse the critical dilemmas that Albert Herring provoked. The very fact that critics have found it impossible to resist trying to locate within it an original voice that has consistently eluded them suggests that modernist oppositions between tradition and innovation are much easier to denounce than to displace. While it is commonplace to comment on the "inimitable" quality or "distinctiveness" of Britten's voice, writers have had a tough time describing it. ${ }^{99}$ Just as Crozier implied hermeneutic surplus by highlighting a lack, we might hear the composer marking out his musical originality by foregrounding tradition.

\section{MODERNIST TRADITIONS}

Toward the end of Between the Acts, the audience can be overheard debating the merits and meanings of the pageant they have just witnessed: while one enthusiastic spectator dubs it "brilliantly clever," another dismisses it as "utter bosh." ${ }^{100}$ The only thing upon which they agree is that the play's meaning is less than clear; its eclectic patchwork of literary pastiche is just too random; its welter of disparate voices too incongruous. As Isa, Giles, and Mr. Oliver survey the pageant before retiring for the day, they too agree to disagree, each seeing something different in its "orts, scraps and fragments." ${ }^{101}$ Given that Woolf's novel is as eclectic as the artwork it describes, it should come as no surprise that its reception mirrored the critical ambivalence it portrayed. ${ }^{102}$ The novel thematizes and draws upon a number of conflicting styles and aesthetics, while ultimately favoring none, making it difficult to establish where its sympathies lie. Is it with the nostalgic "old fogies," 
who want to hear the same old stories sung to the same old tunes, or with the modernists, "the young, who ... shiver into splinters the old vision; smash to atoms what was whole"? ${ }^{103}$ More importantly, why has it mattered so much, whether to early critics or more recent scholars?

Although mid-century preoccupations with artistic timeliness were often clothed in politicized rhetoric, they rested on long-standing aesthetic concerns. By the early 1920s, Woolf was one of many to assert an artist's resistance to tradition as central to the value of his or her art. ${ }^{104}$ By the 1930s, the Leavises were systematically mapping timeliness and tradition, along with other related oppositions-seriousness versus triviality, convention versus innovation-onto the "great divide." While popular fiction was said to exploit conventional pleasuresfamiliar story lines, characters, and phrases that offered escape from the problems of the modern world-its highbrow counterpart was supposed to disrupt them with radically new musical ideas. ${ }^{105}$ Such disruption was often aligned with thematic timeliness, as if employing up-to-date styles and techniques necessarily got audiences pondering pressing themes of war, oppression, and lost innocence. In anxiously stressing the timeliness and seriousness of Between the Acts, critics and commentators were-in other words-making claims not just about political relevance but about Woolf's modernism too.

Something similar may be observed in the defensive reactions to Albert Herring. By explaining away elements of convention and redirecting attention toward more timely aspects, early critics sought to secure a place for Britten's opera on the "right" side of the great divide. What is more, this defensiveness has only increased in scholarship since. Before echoing all the old defenses, Peter Evans, for one, dismissed the possibility that "Britten's purpose in writing Albert Herring could have been no more than a wish to entertain by apt caricature of the familiar." ${ }^{106}$ In framing his queer reading as an antidote to the opera's apparent nostalgia and conservatism, Philip Brett, for another, invoked them again: "if Britten had not reached, consciously or unconsciously, for something beyond caricature and condescension and had merely produced a cosy little provincial romp in the spirit of the escapist Ealing comedies of the period, the opera would not have survived so well. ${ }^{107}$ Even as recently as 2003, Brian Young advanced a socialist interpretation in the same apologetic spirit, as if to uncover a "timely" response to postwar politics was necessarily to erase the opera's conventionality. ${ }^{108}$ While mid-century critics were relatively candid about their aesthetic judgments, scholars have tended to couch their defenses in terms of political or social relevance. Their recourse to the same defensive rhetoric, withal, raises the possibility of "politics" serving as a proxy for aesthetic distinctions. Donald Mitchell concluded "The Serious Comedy of Albert Herring" - the essay that set the scholarly tone-with an absolute assertion of aesthetic value, suggesting that it was the composer's modernism all along that has been at stake. ${ }^{109}$

In continuing to pose critical problems for even recent scholars, Herring suggests that modernist oppositions between tradition and innovation, timeliness 
and tradition, live on in the way we structure our histories. But while defensive approaches to such ostensibly conventional works tend to reinforce modernist oppositions, Albert Herring shows how easily they broke down. Whether stressing affinities with more overtly timely operas, explaining away its traditionalism as ironic, or focusing on its more self-consciously modernist features, critics were torn between their enjoyment of and embarrassment at Herring's flagrantly conventional tropes and styles. ${ }^{110}$ Yet it was this very self-consciousness that allowed them to have it both ways. By combining an eclectic welter of old and new voices with critical defensiveness, Herring's audiences could apparently enjoy both tradition and timeliness. While some critics cast Britten's comic opera as something of a middle ground between the dogmatic reverence to tradition and extreme revulsion against it, others cast its success in more dialectical terms: "Modern he [Britten] is-but into his modernity is crystallized a thorough knowledge of and respect for the music of his great predecessors." ${ }^{\prime \prime 1}$ As an opera that could carry the burden of such tensions and contradictions, in other words, Albert Herring acted as an unflattering mirror for musical modernism more generally, simultaneously reveling in and disavowing its own conventionality. 